\title{
Seed dispersal in the Iberian pear, Pyrus bourgaeana: A role for infrequent mutualists ${ }^{1}$
}

\author{
Jose M. FEDRIANI ${ }^{2}$ \& Miguel DELIBES, Estación Biológica de Doñana (CSIC), Avda. Américo Vespucio s/n, \\ Isla de la Cartuja, ES-41092, Sevilla, Spain, e-mail: fedriani@ebd.csic.es
}

Abstract: Seed dispersal by animals is a key interaction, with effects on the population ecology and evolution of many plant
lineages. Despite the fact that infrequent seed dispersers can potentially provide important services to plant populations, little
attention has been paid so far to scarce mutualists. We assessed different aspects of quantity and quality of seed dispersal
from fruit removal to seed germination in the Iberian pear, Pyrus bourgaeana, finding that fruit consumers markedly differed
in the nature of their interaction with the tree. Whereas the abundant rodents, rabbits, and deer damaged all seeds eaten, the
uncommon carnivores badger and fox and the abundant boars dispersed a large fraction of ingested seeds as viable propagules,
acting as legitimate seed dispersers. Despite low rates of visitation by badgers to fruiting trees, they transported more viable
seeds than the abundant boars, due to better seed treatment and a higher feeding rate on pears. Seed dispersal by all 3 legitimate
dispersers, especially the badger, enhanced post-dispersal $P$. bourgaeana seed survival, supporting the "escape" predation
hypothesis. Pyrus bourgaeana showed relatively high frequencies of visits by a myriad of frugivores; however, it relied on the
dispersal service provided by an infrequent carnivore, the badger, rather than on those provided by the abundant mammalian
herbivores. Therefore, under some circumstances, uncommon animal counterparts play major roles in their mutualistic
interactions with flowering plants.
Keywords: badger, carnivorous mammals, "escape" hypothesis, frugivory, infrequent mutualists, Meles meles, post-dispersal seed survival, seed dispersal.

Résumé : La dispersion des graines par les animaux est une interaction clé ayant des effets sur l'écologie des populations et l'évolution de plusieurs lignées de plantes. Malgré le fait que des agents de dispersion des graines peu fréquents ont le potentiel de fournir des services importants aux populations végétales, les mutualismes rares ont reçu peu d'attention jusqu'à maintenant. Nous avons évalué les différents aspects de la quantité et de la qualité de la dispersion des graines, de la cueillette du fruit jusqu'à la germination de la graine chez le poirier Pyrus bourgaeana, et constaté que les consommateurs de fruits différaient grandement entre eux dans la nature de leur interaction avec l'arbre. Alors que les abondants rongeurs, lapins et cerfs endommageaient toutes les graines ingérées, les carnivores rares (le blaireau et le renard) et les abondants sangliers dispersaient une grande partie des graines ingérées en tant que propagules viables, agissant ainsi comme agents légitimes de dispersion des graines. Malgré les faibles taux de visite aux arbres fruitiers par des blaireaux, ceux-ci ont transporté plus de graines viables que les abondants sangliers en raison d'un meilleur traitement des graines et d'une plus grande consommation de poires. La dispersion des graines par les 3 agents légitimes de dispersion, particulièrement le blaireau, a augmenté la survie postdispersion des graines de P. bourgaeana, supportant l'hypothèse « d'évasion » de la prédation. Pyrus bourgaeana a été visité relativement fréquemment par une myriade de frugivores; cependant, la dispersion des graines a été mieux assurée par un carnivore peu fréquent, le blaireau, que par les abondants mammifères herbivores. Donc, dans certaines circonstances, les animaux rares jouent des rôles principaux dans leurs interactions mutualistes avec les plantes à fleurs.

Mots-clés : blaireau, dispersion des graines, frugivorie, hypothèse "d'évasion ", mammifères carnivores, Meles meles, mutualistes peu fréquents, survie des graines postdispersion.

Nomenclature: Váldes et al., 2007.

\section{Introduction}

Seed dispersal by animals is a pervasive interaction of paramount importance for the population ecology and evolution of many plant lineages (Herrera, 2002; Wang \& Smith, 2002; Russo, 2003; Howe \& Miriti, 2004; Giladi, 2006). For a particular plant species, animal dispersers are likely to differ not only in the number of handled seeds (i.e., quantity of dispersal) but also in the probability of delivering viable seeds to sites with low risk of predation and high prospects for seedling establishment (i.e., quality of

${ }^{1}$ Rec. 2009-01-05; acc. 2009-05-01.

Associate Editor: Stephen Vander Wall.

${ }^{2}$ Author for correspondence.

DOI 10.2980/16-3-3253 dispersal; Jordano \& Schupp, 2000). Although the distinction between the 2 components of dispersal effectiveness, quantity and quality, has long been recognized (Schupp, 1993), an assessment of the importance of these 2 factors is lacking for most plant-disperser systems. Within disperser assemblages, there often exists a positive correlation among the abundance of different fruit consumers and their frequencies of visit to fruiting plants and, ultimately, with the number of seeds handled (Vázquez et al., 2005; Burns, 2006). Nonetheless, the total number of seeds handled depends not only on interaction frequency, but also on the number of seeds handled per interaction. Therefore, infrequent visitors (e.g., uncommon species) can potentially be important dispersers for plant populations (e.g., Russo, 
2003; Brodie et al., 2009). However, detailed documentation of the services provided by dispersers is even more limited for uncommon animal vectors, such as carnivorous mammals (e.g., mustelids, canids; Herrera, 2002), limiting our understanding of the level of generalization of many plant populations with respect to dispersers.

Addressing this question entails the laborious task of accounting for both the quantity (frequency of visits, number of seeds handled) and the quality of dispersal in a focal plant population. Seed treatment, dispersal distance, and microhabitat of deposition are among the most central aspects of dispersal quality (Jordano \& Schupp, 2000; Nathan \& Muller-Landau, 2000; Spiegel \& Nathan, 2007). In particular, in locations where post-dispersal pathogens or seed/seedling predators are abundant, distance from mother tree may greatly affect the survival of seeds and seedlings (Janzen, 1970; Connell, 1971). The "escape" hypothesis posits that seeds dispersed away from mother trees escape an almost certain death due to distance- or density-dependent responses of herbivores, a prediction validated by numerous field studies (Howe \& Smallwood, 1982; HilleRisLambers, Clark \& Beckage, 2002; but see Hyatt et al., 2003). However, post-dispersal seed predators also may respond to factors other than seed density or distance to mother tree (Hammond \& Brown, 1998), such as presence of heterospecific seeds at the place of arrival (Peters, 2003; Kwit, Levey \& Greenberg, 2004) or cover provided by adult heterospecifics, influencing the foraging of seed predators (Brown \& Kotler, 2004); thus, survival may vary at a microscale for both dispersed and nondispersed seeds. Nevertheless, few studies have assessed the combined effects of seed dispersal distance (beneath or away from mother plants) and microhabitat of deposition on seed survival (Augspurger, 1983; 1984), despite their predictable critical implications for the quality of dispersal provided by different vectors.

To assess the relative importance of frequent and infrequent frugivorous visitors for plant dispersal, we chose the Iberian pear, Pyrus bourgaeana (Decne, 1871), and its seed dispersers. Several abundant mammalian herbivores and some scarce "carnivores" with conspicuously contrasting feeding habits and patterns of defecation consume P. bourgaeana fruits in a Mediterranean scrubland of southwestern Spain. We evaluated different quantitative and qualitative aspects of seed dispersal by these fruit consumers, from fruit removal to early post-dispersal seed fate, and assessed the tree's level of generalization with respect to seed dispersers. We predicted that fruit consumers with low population densities (i.e., mammalian carnivores) would be infrequent visitors and, thus, that they could be major dispersers of $P$. bourgaeana seeds only if they showed a higher quality of dispersal and/or higher per interaction effect than more abundant frugivores. Because the overall dispersal service provided by a frugivore is the product of both the quantitative and the qualitative dispersal components (Schupp, 2007), whenever for a particular $P$. bourgaeana visitor any component approaches zero, this visitor should be regarded as a poor seed disperser. Consequently, P. bourgaeana could have a variable assemblage of dispersers, depending on the overall dispersal service provided by its fruit consumers. To assess the role of frugivorous visitors, we first examined the extent of variation among them in their frequency of visits to fruiting trees and in the relative number of seeds handled by each species (i.e., quantity of seed dispersal). We then assessed the extent of interspecific variation among frugivores in their seed treatment during ingestion and in their microsites of deposition (i.e., qualitative aspects of seed dispersal). Finally, we experimentally determined microhabitat-specific seed survival beneath and away from mother trees, linking seed survival to disperser-specific microhabitat of deposition. We discuss our results in relation to P. bourgaeana dispersal strategy (i.e., generalized versus specialized).

\section{STUDY SITE}

The study was carried out during September-February of 2005-2006 and 2006-2007 in the Doñana National Park $\left(510 \mathrm{~km}^{2} ; 37^{\circ} 9^{\prime} \mathrm{N}, 6^{\circ} 26^{\prime} \mathrm{w}\right.$; elevation $\left.0-80 \mathrm{~m}\right)$, located on the west bank of the mouth of the Guadalquivir River in southwestern Spain. Our focal P. bourgaeana population occurs within a Mediterranean scrubland dominated by Pistacia lenticus shrubs (2-3 m high) growing singly or in small clumps separated by either unvegetated space or a sparse understory of Halimium halimifolium, Ulex spp., Cistus spp., Chamaerops humilis, and Myrtus communis (Fedriani, Palomares \& Delibes, 1999). Scattered across the study area there are Quercus suber, Olea europaea var. sylvestris, and Fraxinus angustifolia trees (Fedriani, Palomares \& Delibes, 1999). The area is located mostly on a sandy substrate where $P$. bourgaeana trees grow. A considerable part of our fieldwork (see below) was undertaken in a tetragonal plot of 72 ha $(\sim 0.6 \times 0.9 \times 0.8 \times 1.0 \mathrm{~km})$. Most of the plot (49 ha) is occupied by Mediterranean scrubland as detailed above, but its southwestern portion (23 ha) is occupied by a "dehesa" of scattered $Q$. suber and $O$. europaea var. sylvestris trees with a sparse understory of Mediterranean shrubs (Fedriani, Wiegand \& Delibes, 2009). The climate is Mediterranean sub-humid, characterized by dry, hot summers (June-September) and mild, wet winters (November-February). Annual rainfall varies widely, ranging during the last 15 y between 170 and $1028 \mathrm{~mm}$ (mean $\pm \mathrm{SE}, 540 \pm 63 \mathrm{~mm}$ ), with most rain falling during the winter $(310.7 \pm 51.4 \mathrm{~mm})$ and extreme drought occurring during the summer $(34.1 \pm 7.9 \mathrm{~mm}$; data from Natural Processes Monitoring Group, Doñana Biological Station, http://www-rbd.ebd.csic.es/Seguimiento/seguimiento.htm).

Pyrus bourgaeana (Rosaceae), a close relative of the domestic pear Pyrus communis (Aldasoro, Aedo \& MuñozGarmendia, 1996), is a monoecious small tree (typically 3-6 m high) that flowers during February-March. Each tree produces 200-450 fruits that ripen and fall to the ground during a 5-month period (September-January; Jordano, 1984). Developed fruits are globose pomes $(2-3 \mathrm{~cm}$ diameter; $\sim 9.5 \mathrm{~g}$ wet weight) that contain a sugary water-rich pulp (Herrera, 1987). Each fruit includes 1-5 viable seeds (46-91 mg each; Fedriani \& Delibes, 2009) with thin and easily breakable coats. Pre-dispersal seed losses by invertebrates (microlepidoptera larvae) are generally low $(<5 \%$; J. M. Fedriani \& M. Delibes, unpubl. data). In Doñana, $P$. bourgaeana is relatively scarce, and individuals are typically aggregated from a small (a few metres to hundred of metres) 
to a landscape (tens of kilometres) scale across the scrubland (Fedriani, Wiegand \& Delibes, 2009). Based on fruit traits, mammals have been assumed to be the main dispersers of P. bourgaeana seeds, whereas birds (e.g., Blackcap [Silvia atricapilla], Azure-winged magpie [Cyanopica cianus]) act as pulp-predators rather than seed dispersers (Jordano, 1984; 1995). Because seed germination in P. bourgaeana apparently requires removal of the attached fruit pulp, fruit processing by mammals is an important service for the tree (i.e., most seeds within fallen fruits decay at the end of the dispersal season; Fedriani \& Delibes, 2009). Seedlings emerge from late February to late April, and extensive seedling mortality occurs during the first summer due to droughts (Fedriani \& Delibes, 2009).

Prior to this study, remains of $P$. bourgaeana fruit were found in the feces of red foxes (Vulpes vulpes; $5-7 \mathrm{~kg}$ ) and Eurasian badgers (Meles meles; 6-8 kg) collected at our study site (Fedriani, 1996; Fedriani, Ferreras \& Delibes, 1998), where these omnivorous mammals (Order Carnivora) occur in relative low densities (Table I). Because ungulates (wild boar, Sus scrofa [40-50 kg]; red deer, Cervus elaphus [40-80 kg]) and lagomorphs (European rabbit, Oryctolagus cuniculus $[\sim 1 \mathrm{~kg}]$ ) disperse seeds of numerous fleshyfruited plant species (e.g., Soriguer, 1983; Santos, Tellería \& Virgós, 1999; Calviño-Cancela, 2002; Eycott et al., 2007; Dellafiore, Gallgo-Fernádez \& Munoz-Vallés, 2007) and are very common in Doñana (Table I), they were also presumed to be potential seed dispersers of $P$. bourgaeana. Up to 6 species of granivorous rodents (Apodemus sylvaticus, Mus spretus, Mus musculus, Rattus rattus, Rattus norvegicus, Eliomys quercinus; Kufner, 1986) that could consume P. bourgaeana fruits and seeds also occur in the area.

TABLE I. Relative abundances estimated during this study (September 2005 and 2006) and population densities estimated during previous studies (and source) of main P. bourgaeana fruit consumers in the Doñana National Park (SW Spain). Relative abundances of these mammals were estimated in our study site in September 2005 and 2006 during visual censuses (carried out around sunset) from a vehicle along a fixed transect $(14.8 \mathrm{~km})$ that traversed our study site. Because we did not see any carnivore during the visual surveys during December 2005 and 2006, we also carried out carnivore track censuses along a fixed transect $(2 \mathrm{~km})$ that traversed our study site (see Palomares et al., 1995 for further methodological details).

\begin{tabular}{|c|c|c|c|c|}
\hline \multirow[t]{2}{*}{ Species } & \multicolumn{2}{|c|}{ Relative abundance } & \multirow[b]{2}{*}{$\begin{array}{l}\text { Density } \\
\text { (ind } \cdot \mathrm{km}^{-2} \text { ) }\end{array}$} & \multirow[t]{2}{*}{ Source } \\
\hline & $\begin{array}{l}\text { Tracks } \\
\text { (per km) }\end{array}$ & $\begin{array}{l}\text { Sighting } \\
(\text { per km) }\end{array}$ & & \\
\hline $\begin{array}{l}\text { Eurasian badger } \\
\text { Meles meles }\end{array}$ & $4.0-7.5$ & 0 & $0.2-0.7$ & $\mathrm{a}, \mathrm{b}$ \\
\hline $\begin{array}{l}\text { Red fox } \\
\text { Vulpes vulpes }\end{array}$ & $0.0-1.5$ & 0 & $0.5-0.8$ & $\mathrm{a}, \mathrm{b}$ \\
\hline $\begin{array}{l}\text { Wild boar } \\
\text { Sus scrofa }\end{array}$ & - & $0.3-0.6$ & $1.4-9.4$ & $\mathrm{~b}, \mathrm{c}$ \\
\hline $\begin{array}{l}\text { Red deer } \\
\text { Cervus elaphus }\end{array}$ & - & $1.2-1.8$ & 54 & $\mathrm{~d}, \mathrm{~b}$ \\
\hline $\begin{array}{l}\text { European rabbit } \\
\text { Oryctolagus cunniculus }\end{array}$ & - & $2.5-4.2$ & $200-1830$ & $\mathrm{~b}, \mathrm{e}$ \\
\hline
\end{tabular}

${ }^{1}$ Source: a, Fedriani, Palomares \& Delibes, 1999; b, Data from "Natural Processes Monitoring Group", Doñana Biological Station (http://wwwrbd.ebd.csic.es/Seguimiento/seguimiento.htm); c, Fernández-Llario, 1996; d, Braza et al., 1984; e, Palomares et al., 2001.

\section{Methods}

Throughout this manuscript, we refer to "non-dispersed seeds" as those fallen, generally within ripe fruits, beneath the mother trees. "Primary" seed dispersal (or predation) refers to seed movements from fallen fruit under the mother tree to final destination. "Secondary" dispersal refers to seed movements from mammal feces containing seeds to final destination. A number of observational and experimental approaches were used to investigate seed fate. To estimate the species-specific frequency of visits to fruiting trees, we placed ripe fruit beneath experimental trees and monitored fruit removal. Data from collection and analysis of feces were used to examine variation in seed treatment, number of seeds dispersed, distance to nearest conspecific, and microhabitat of seed delivery by different frugivores. Finally, microhabitat-specific seed survival was estimated by means of seed predation field experiments and then linked to disperser-specific microhabitat of deposition.

\section{FRUGIVORE VISITATION OF FRUITING TREES}

We first assessed the quantitative importance of different frugivores by estimating the number of visits to $P$. bourgaeana trees during two 4-d periods, one in September (20 trees) and the other in November (19 trees) of 2006. We attempted to use the same individual trees in field experiments; however, because some trees did not have enough available fruits in November, we used 8 new trees. This is unlikely to have affected our results, as those trees were close to the ones used in September and the rate of visits and the identity of visitors were rather consistent across trees in both months (see below). Because in Doñana most fruit removal occurs once ripe fruit has fallen to the ground (local mammals do not show arboreal habits), for each focal tree 20 of its ripe fruits were offered beneath it (simulating non-dispersed seeds) within a circular plot (3 $\mathrm{m}$ diameter) of sandy substrate. In each plot, fruits were regularly set in 4 lines (5 fruits per line) about $20 \mathrm{~cm}$ apart. Direct observations of foraging frugivores are impractical (Fedriani \& Kohn, 2001); thus, visitor identification and an estimate of relative visitation rates were achieved through identification of their footprints in the sandy substrate (e.g., Balcomb \& Chapman, 2003; Mendoza \& Dirzo, 2007). This approach allowed us to differentiate 7 taxonomical categories of visitors (badger, fox, boar, deer, rabbit, rodents, and birds). In both fruit removal experiments, offered fruits were checked early in the morning during 4 consecutive days and the number of remaining fruits was recorded. In some instances, more than 1 species had visited a tree during a particular night and, thus, the identity of the fruit remover was questionable (i.e., some visitors may not have removed any fruit). Therefore, when fruit removal took place, we first considered all visits (i.e., single plus multiple visitors) and then we considered only those visits made by single visitors, for which remover identification was conclusive. Footprints were cleaned at the start of each 4-d field experiment and again after each observation.

\section{SEED TREATMENT AND NUMBER OF DISPERSED SEEDS}

We analyzed fecal samples to verify whether the presumed seed dispersers actually consumed $P$. bourgaeana 
seeds and, if so, to assess the quality of treatment of ingested seeds. Because of the scarcity or low detectability of bird and rodent feces, our collection of fecal samples was restricted to foxes, badgers, boars, deer, and rabbits. A significant effort was made to distribute our sampling effort homogeneously across the 72-ha study plot. We chose a total of 12 "starting points" regularly distributed along the plot edge. During each fecal sampling survey, an observer walked from a starting point (which changed methodically among consecutive surveys) following a non-fixed zigzagging trajectory to the opposite side of the plot and returning following a different path to a different point on the side of departure. Each survey took about $2 \mathrm{~h}$, and overall we undertook 104 different surveys ( 208 observer-hours). On average, each starting point was used 8.7 times. Based on a sample of 21 surveys for which distance traveled was measured (using a GPS), we walked a minimum of $295 \mathrm{~km}$ searching for mammal feces within the plot (whose longest side is $1.0 \mathrm{~km}$ ). Fecal surveys were carried out weekly during the fruiting seasons (September-January) of 2005-2006 and 2006-2007 for carnivores and ungulates. In an attempt to achieve similar sample sizes, we collected any fresh fox or badger feces (which were locally scarce) but only up to the first 5 deer and boar feces (which were relatively abundant) found during each survey. For rabbit, surveys were done once per month and up to 30 fecal samples were collected per survey. Overall sample sizes were 168, 140, 112, 81 , and 22 for rabbit, badger, boar, deer, and fox, respectively. Fecal samples were air dried and stored individually in paper bags. Each sample was washed thoroughly under running water on a sieve $(0.50 \mathrm{~mm}$ mesh size $)$ and air-dried. Seeds and other fruit remains (skin, pulp, pedicels, etc.) were identified using a reference collection. Further, seeds were examined with a 20-40× magnification glasses and the numbers of intact and damaged (i.e., crushed or fractured) $P$. bourgaeana seeds were recorded. Particular care was taken to detect any seed coat remains, which would denote the presence of broken seeds. When seed coat remains were present, we estimated the number of entire seeds that would best account for them (e.g., Herrera, 1989). The frequency of occurrence of fruit remains in feces was estimated for each mammal species each sampling season as (number of feces with fruit remains / total number of feces) $\times 100$.

We further explored the quality of seed treatment by each disperser by assessing the ability of intact seeds to germinate after ingestion by mammals. We extracted seeds from mammal feces collected during autumn of 2005-2006 and sowed them in pots $(7 \mathrm{~cm}$ diameter) filled with local sandy substrate at our field station in Doñana under natural conditions of precipitation and photoperiod. From 3 to 10 seeds were sowed per pot at $\sim 1 \mathrm{~cm}$ depth. Seed sowings were checked weekly for seedling emergence from February until May. Finally, to estimate the number of seeds consumed by legitimate dispersers, we could not simply compare the overall number of $P$. bourgaeana seeds found in their feces, as we generally did not collect all found feces for all mammal species (see above). Therefore, in order to attain a comparable metric, we considered the subset of surveys (34 out of 104) for which all found feces were collected and then calculated the number of seeds in feces of each species per survey. Because this approach is not biased towards any one species, it leads to a valid interspecific comparison of the number of dispersed seeds.

\section{COMBINED EFFECT OF DISPERSAL AND MICROSITES OF DEPOSITION ON SEED SURVIVAL}

To evaluate whether different potential dispersal agents moved $P$. bourgaeana seeds away from trees, we obtained a GPS reading for each mammal fecal sample found during the fecal surveys and recorded it in a geographic information system to establish its map location (using ArcView software). All fruiting trees $(n=75)$ in the 72-ha plot were also mapped, and the distances among fecal deposition sites and the nearest tree were calculated for the subset of feces comprising P. bourgaeana seeds. To account for potential edge effects on our estimates of "minimal dispersal distance", we considered all trees $(n=4)$ located within a 50-m buffer around the entire plot. Obviously, some dispersed $P$. bourgaeana seeds likely came from a source tree other than the nearest one (either inside or outside of the study plot); thus, our estimate is not the actual dispersal distance but can be considered to be the "minimal dispersal distance". Therefore, we used these estimates only to illustrate the potential of dispersal agents to move $P$. bourgaeana seeds away from mother trees. In addition, we identified the most typical microhabitats of deposition by each mammal species. Because other microhabitat features (substrate, topography) varied only slightly, we focused on vegetation by visually estimating the proportion of the area occupied by each shrub or tree species within 1-m radius around each fecal sample (at both $<1 \mathrm{~m}$ and $\geq 1 \mathrm{~m}$ height).

Dispersers delivered most seeds within Pistacia shrubs or in open microsites (see Results). Thus, the effect of vegetation cover on seed survival was assessed by means of seed depredation experiments in those 2 microsites. To assess the combined effect of dispersal and vegetation cover on seed survival, we chose 21 P. bourgaeana trees that all had the area beneath their crown occupied by Pistacia and unvegetated space (a locally recurrent circumstance; see Study site). For the experiment, we used a $2 \times 2$ factorial design whose factors were "Tree" (beneath or away [i.e., at $\sim 20 \mathrm{~m}$ ] from a reproductive tree) and "Cover" (inside Pistacia shrub or in open microsite). Thus, each tree or random block comprised 4 microhabitats: 1) beneath P. bourgaeana tree (i.e., simulating non-dispersed seeds) and inside Pistacia; 2) beneath P. bourgaeana tree and in open microsite (within 2-4 m of any Pistacia); 3) away from $P$. bourgaeana tree (i.e., simulating dispersed seeds) and inside Pistacia; and 4) away from P. bourgaeana tree and in open microsite. In each random block, we set 1 seed depot per microhabitat (i.e., 4 seed depots per block; overall, 84 seed depots). Each seed depot consisted of a Petri dish containing 10 filled seeds previously collected from neighbouring trees. The field experiment was carried out early in February 2007, when heavy winter rains had buried most dispersed seeds; thus, offered seeds were buried (about $1 \mathrm{~cm}$ deep) within sandy substrate to resemble their natural presentation. Because seed survival was used for comparative reasons and to facilitate daily checking of seed depots, seeds were not mixed with feces of any particular disperser 
(e.g., Willson \& Whelan, 1990; Rey et al., 2002; Paine \& Beck, 2007). Seed depots were checked early in the morning during each of 3 consecutive days, and the number of seeds remaining was recorded. Densities of heterospecific seeds (e.g., P. lentiscus, $Q$. suber) did not seem to vary with distance to mother trees (J. M. Fedriani \& M. Delibes, pers. observ.); in addition, our factorial blocking-design allowed us to account for any potential spatial variation of important environmental factors (e.g., background food; Fedriani \& Manzaneda, 2005).

To further evaluate relative risk of seed predation and to know the species of granivorous rodents involved, we conducted a small-mammal trapping survey around the same trees (during mid February), as those used in the seed predation experiment and also following the same factorial design. Four Sherman traps (1 per microhabitat; see above) were baited with peanut butter and set at each of the 21 trees during 4 consecutive nights (overall, 336 trap-nights). Traps were checked daily within $3 \mathrm{~h}$ after sunrise, and captured animals were individually marked with indelible ink on the tail (lasting for at least $7 \mathrm{~d}$; Fedriani, 2005) and directly released at their capture sites. For each microhabitat, we estimated a simple index of rodent trappability as (total number of captures [i.e., irrespective of the individual] $\times 100$ )/trapping effort (i.e., number of trap-nights). Recaptures of the same individual were considered in our estimate of trappability, thus leading to an index of microhabitat usage by granivorous rodents (i.e., risk of seed predation) rather than an index of abundance of different species.

\section{STATISTICAL ANALYSES}

Differences in the frequencies of visitors to fruiting trees, the occurrence of fruit remains in feces, the occurrence of intact and damaged seeds in feces, and raw data on percent of seed germination were evaluated by chi-square analyses of contingency tables or by Fisher exact tests using SAS PROC FREQ (SAS Institute, 2003). Low abundance of mammals or logistic limitations prevented us from attaining adequate sample sizes for some species during each of the fruiting seasons (Table II); therefore, and for sake of simplicity, interspecific differences in the frequency of occurrence of fruit remains and damaged versus intact seeds in feces were tested over a pooled data set comprising both fruiting seasons. Nonetheless, the results of that pooled data set were clearly consistent with the results obtained when analyzing data separately for each sampling season. Several of our results were analyzed by fitting generalized linear mixed models using the SAS macro GLIMMIX (Littell et al., 1996), which enables the modeling of non-normal response variables as well as usage of both fixed and random factors. For response variables such as proportions (number of fruits [or seeds] remaining / initial number of fruits [or seeds], mice relative abundance, etc.) we used binomial error and logit link function, whereas for counts (i.e., number of seeds in feces) we used Poisson error and log link function. When appropriate, experimental block (tree, date of sampling) was included as a random factor to control for its potential effect (Bennington \& Thayne, 1994). When the interaction between any 2 factors was significant, we performed tests for the effect of a given factor at the different levels of the other factor ("tests of simple main effects") using the SLICE option in the LSMEANS statement of the MIXED procedure (Littell et al., 1996). In analyzing data from our seed predation experiment (i.e., seed survival), a linear model using seeds remaining after 3 nights did not converge (likely because of too many zero values); thus, we used the number of seeds remaining after 2 nights of exposure to seed predators as the response variable (e.g., Fedriani et al., 2004). For all models, adjusted means and standard errors were calculated using the LSMEANS statement and back-transformed using the appropriate Taylor's series approach (Littell et al., 1996).

\section{Results}

\section{FRUGIVORE VISITATION OF FRUITING TREES}

During both 4-night fruit removal experiments, mammals were clearly the main terrestrial visitors, accounting for $96 \%$ of all visits $(n=146$ visits of the 7 defined categories) and visiting all 28 experimental trees. Other than mammals, birds were the only frugivorous visitors; however, as indicated by our extensive observations at fruiting trees, birds left bitten fruits and seeds beneath mother trees and thus behaved as pulp feeders. Therefore, birds were not further considered as seed dispersers. Trees were generally visited by 1 (i.e., single visitors) or 2 mammal categories $(86.2 \%$ of cases; $n=116)$. In the remaining cases $(13.8 \%)$, fruiting trees were visited by up to 4 different

TABLE II. Frequency of occurrence of $P$. bourgaeana fruit remains and percentages of intact seeds in feces of Eurasian badger, red fox, wild boar, European rabbit, and red deer collected between September and January of 2005-2006 and 2006-2007, respectively, in the Doñana National Park (SW Spain). Mean number of intact seeds per fecal sample and percentages of germination of seeds extracted from mammal feces ( $n$, number of seeds sowed) are also shown.

\begin{tabular}{|c|c|c|c|c|c|c|c|c|c|c|c|c|c|c|c|}
\hline & \multicolumn{3}{|c|}{ Eurasian badger } & \multicolumn{3}{|c|}{ Red fox } & \multicolumn{3}{|c|}{ Wild boar } & \multicolumn{3}{|c|}{ Red deer } & \multicolumn{3}{|c|}{ European rabbit } \\
\hline & 2005 & 2006 & Overall & 2005 & 2006 & Overall & 2005 & 2006 & Overall & 2005 & 2006 & Overall & 2005 & 2006 & Overall \\
\hline Frequency of occurrence $(\%)$ & 47.9 & 40.9 & 46.7 & 19.1 & 0 & 18.2 & 8.8 & 7.7 & 8 & - & 4.9 & 4.9 & 5.6 & 16.7 & 15.5 \\
\hline Percentage of intact seeds & 88.3 & 99.2 & 92.1 & 98.7 & - & 98.7 & 48.7 & 88.9 & 56.5 & - & 0 & 0 & 0 & 0 & 0 \\
\hline Overall number of seeds & 1111 & 595 & 1706 & 77 & 0 & 77 & 37 & 9 & 46 & - & $-a$ & $-{ }^{a}$ & $-a$ & $-{ }^{a}$ & $-\mathrm{a}$ \\
\hline $\begin{array}{l}\text { Mean number of intact seeds } \\
\text { per fecal sample }\end{array}$ & 8.2 & 22.3 & 10 & 11 & - & 11 & 2 & 1 & 1.8 & - & $-a$ & $-\mathrm{a}$ & $-\mathrm{a}$ & $-{ }^{a}$ & $-{ }^{a}$ \\
\hline $\begin{array}{l}\text { Number of fecal samples } \\
\text { Percentage of }\end{array}$ & 118 & 22 & 140 & 21 & $1^{\mathrm{c}}$ & 22 & 34 & 78 & 112 & $0^{\mathrm{c}}$ & 81 & 81 & 18 & 150 & 168 \\
\hline germination $(n)$ & \multicolumn{3}{|c|}{$19.7(223)$} & \multicolumn{3}{|c|}{$2.9(34)$} & \multicolumn{3}{|c|}{$6.3(16)$} & \multicolumn{3}{|c|}{$0.0^{\mathrm{a}}$} & \multicolumn{3}{|c|}{$0.0^{\mathrm{a}}$} \\
\hline
\end{tabular}

a All ingested seeds were ground into tiny pieces making quantification impossible.

${ }^{\mathrm{b}}$ Considering only the subset of feces containing intact seeds.

c Low mammal abundance or logistic limitations limited sample sizes. 
mammals during a particular night. Fruit removal took place in $73.3 \%$ of visits, and even when removal did not occur, fruits were usually handled, lightly gnawed, or even tasted by mammalian visitors. Only $30.0 \pm 7.5 \%$ (mean $\pm 1 \mathrm{SE}$ ) and $38.5 \pm 6.5 \%$ of the offered fruits were not removed during the September and November censuses, respectively, a non-significant difference $\left(F_{1,10}=0.38, P=0.549\right)$. As would be expected given their high abundances (Table I), rabbits, deer, and boars, in that order, were the most common visitors, jointly comprising 75.7\% (September; $n=74$ ) and $79.2 \%$ (November; $n=72$ ) of all visits (Figure 1 ). This prevalence of rabbits and ungulates as visitors of fruiting $P$. bourgaeana was consistent both when considering all visitors and when considering only single visitors (Figure 1). Rodents were relatively common visitors although they were never recorded as single visitors (Figure 1). Not surprisingly (Table I), carnivores were quite infrequent visitors, with badger comprising only $4.1 \%$ (September; $n=74$ ) and $1.4 \%$ (November; $n=72$ ) of visits and no fox visit being recorded at our focal trees. Comparing the results of both censuses (i.e., September versus November), there were only marginal differences in the frequencies of visits of different mammal species (Fisher Exact Test, $P=0.063$ ) when considering all visitors and no differences when considering only single visitors (Fisher Exact Test, $P=0.762$ ); this suggests consistency throughout the fruiting season in the identity of fruit consumers. Whereas ungulates and badgers removed whole fruits, rabbits gnawed a single side of handled fruits, consuming part of their pulp and attached seeds and leaving the discarded fruit parts beneath the trees. Rodents (like rabbits) gnawed the fruit surface around nearly all its transversal axis, but unlike rabbits they consumed all or most seeds.

\section{SEED TREATMENT AND NUMBER OF DISPERSED SEEDS}

Feces of the 5 mammals, including the red fox (which did not visit our experimental trees), collected during both

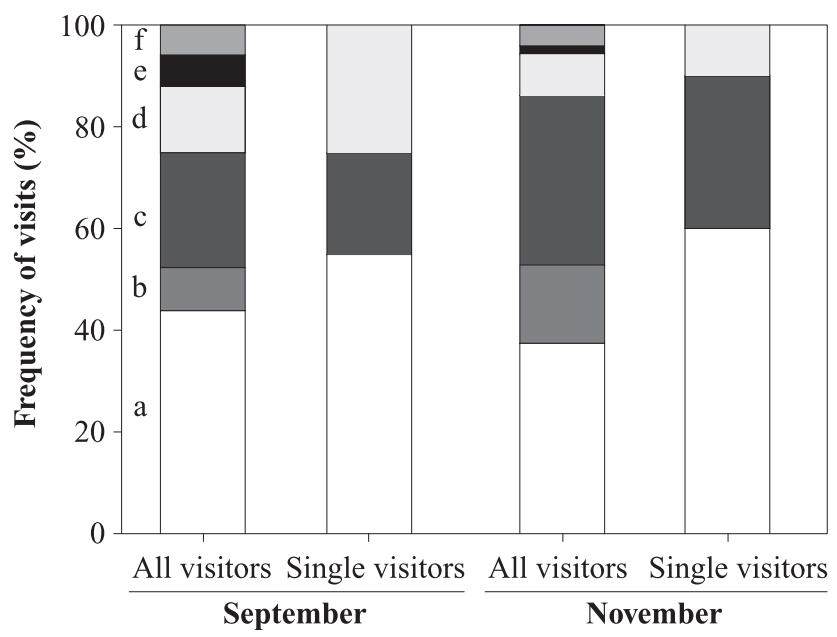

FIGURE 1. Percentages of visits of the defined taxonomic categories to our experimental $P$. bourgaeana fruiting trees during September and November 2006. Visitors were identified on the basis of their distinctive foot tracks in a sandy substrate where fruits were offered. Sample sizes were 74 and 16 (September) and 72 and 13 (November) for all and single visitors, respectively (a, rabbits; b, rodents; c, deers; d, wild boar; e, badger; f, birds). fruiting seasons contained remains of fruits and seeds of P. bourgaeana (Table II). Occurrence of fruit remains in feces, however, varied widely and significantly among species $\left(\chi^{2}=83.63\right.$, df $\left.=4, P<0.0001\right)$. For example, whereas badgers showed a high occurrence of fruit remains (seeds, pulp, skin, etc.) in their feces, boars and deer showed much lower percentages of fruit occurrence (Table II). There were strong and significant interspecific differences in the percentages of damaged and intact seeds $\left(\chi^{2}=562.97\right.$, $\mathrm{df}=4, P<0.0001)$. Foxes and badgers defecated most seeds intact, whereas boars cracked almost half of ingested seeds (Table II). We could not quantify the number of seeds ingested by rabbits and deer, as all seeds were destroyed and ground into tiny pieces (Table II). Therefore, these 2 mammal species are considered to be strictly pre-dispersal seed predators and are not included hereafter in evaluations of disperser effectiveness. For badger, fox, and boar, we further explored the quality of seed treatment by assessing the ability of intact seeds to germinate after ingestion. Even though sample sizes were limited for some species, we found that badger-ingested seeds germinated more often than boar- and fox-ingested seeds $\left(\chi^{2}=7.09\right.$, df $=2, P<0.05$; Table II). These data, in conjunction with our observations in the field of $P$. bourgaeana seedlings emerging from mammal feces (J. M. Fedriani \& M. Delibes, pers. observ.), indicate that at least a fraction of all seeds delivered by badgers, foxes, and boars were viable.

When we considered the subset of surveys in which all found feces were collected, we determined that no $P$. bourgaeana seeds were found in fox feces. For the badger and boar, our generalized mixed linear model indicated that, as expected, the number of seeds found per survey varied among date of collection $(z=2.32, P=0.010)$. After controlling for that random variation, we unexpectedly found that the number of seeds in badger feces collected per survey $(9.35 \pm 5.98)$ was much higher (over 71-fold) than for boars $\left(0.13 \pm 0.12 ; F_{1,13}=21.13, P<0.001\right)$. Furthermore, the difference was even greater when considering only undamaged seeds (i.e., those actually dispersed), the number of undamaged seeds found per survey being $7.24 \pm 5.10$ and $0.07 \pm 0.08$ for badger and boar, respectively $\left(F_{1,13}=17.8, P<0.002\right)$. These data clearly indicate that badgers, despite their relative low abundance, dispersed more $P$. bourgaeana seeds than boars.

COMBINED EFFECT OF DISPERSAL AND MICROSITES OF DEPOSITION ON SEED SURVIVAL

Mean "minimal dispersal distances" were $57.5 \pm 4.6 \mathrm{~m}$ (4-201 m), $24.5 \pm 16.8 \mathrm{~m}(1-74 \mathrm{~m})$, and $71.9 \pm 25.5 \mathrm{~m}$ (5-206 m) for badgers, foxes, and boars, respectively. These results indicate that all 3 mammals usually disperse $P$. bourgaeana seeds at least some distance from the nearest reproductive tree. Although mammal feces were found in a myriad of microsites (14 different shrub types [e.g., P. lentiscus, H. halimifolium, C. humilis, and Ulex spp.], 3 tree species [P. bourgaeana, Q. suber, O. europaea], and open interspaces), most were located either in Pistacia shrubs or in open interspaces. Specifically, badgers, foxes, and boars delivered $42.9 \%$ and $26.4 \%(n=140), 4.5 \%$ and $81.8 \%$ $(n=22)$, and $21.4 \%$ and $44.6 \%(n=112)$ of their feces 
in Pistacia and open microsites, respectively $\left(\chi^{2}=28.00\right.$, $\mathrm{df}=2, P<0.0001)$.

Not surprisingly, we found a significant variation in seed survival across experimental blocks $(z=1.76$, $P=0.039)$ during our seed predation experiment. After controlling for the block effect, both main factors had significant effects on the number of seeds remaining ("Tree", $F_{1,60}=11.67, P<0.002$; "Cover", $F_{1,60}=10.12, P<0.003$; Figure 2a). As predicted, seed survival was generally higher away from trees than beneath them; however, there was a marginally significant interaction effect between "Tree" and
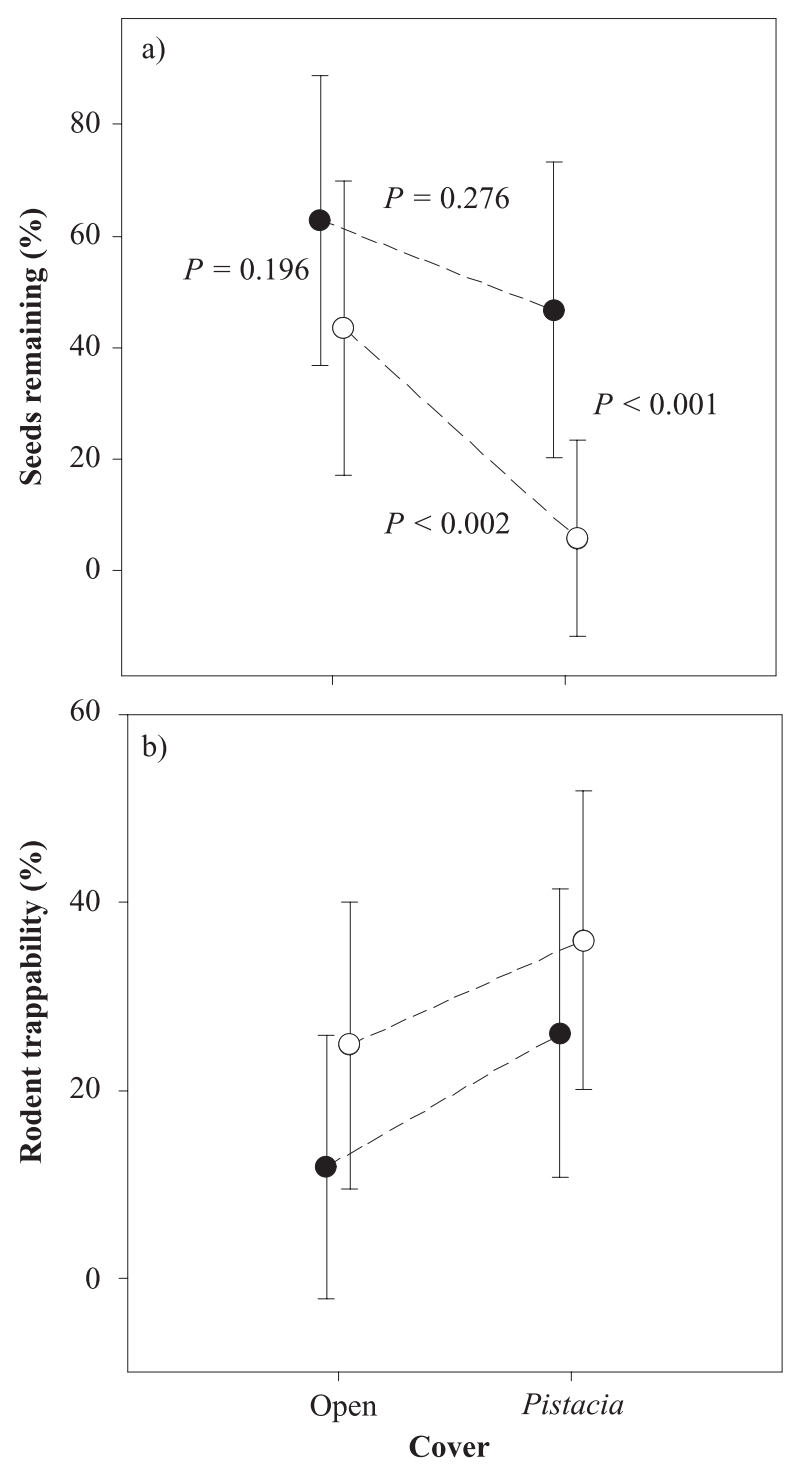

Figure 2. a) Model-adjusted means $( \pm \mathrm{SE})$ of percentages of postdispersal seed predation after 2 consecutive nights in $P$. bourgaeana seed depots (10 seeds each) for 4 microhabitats. These microhabitats resulted from a $2 \times 2$ factorial design whose factors were "Tree" (beneath and away from mother tree [open and filled circles, respectively]) and "Cover" (open or Pistacia). Because of the marginally significant interaction effect between "Tree" and "Cover", we report the $P$-values for the 4 simple main effects involved in the interaction. b) Model-adjusted means $( \pm \mathrm{SE})$ of rodent abundance (i.e., [number of captures plus recaptures $\times 100$ ] per trapping effort [i.e., number of trap-nights]) for the 4 microhabitats described above.
"Cover" $\left(F_{1,60}=3.59, P=0.063\right.$; Figure 2a). Indeed, tests of simple main effects indicated that beneath mother trees Pistacia decreased seed survival (by 7.6-fold) in relation to open cover $\left(F_{1,60}=10.05, P<0.002\right)$; however, away from the mother tree, "Cover" (Pistacia versus open) did not have a significant effect on seed survival $\left(F_{1,60}=1.21, P=0.276\right)$.

During our seed predation experiment, the presence of tracks and feces indicated that rodents (not rabbits, birds, or invertebrates) were responsible for seed removal, and the remains of testa in most seed depots confirmed that they acted as seed predators. Overall, we recorded 86 capture events (i.e., captures plus recaptures) of 52 different individuals of 4 species of granivore rodents. The species captured were Apodemus sylvaticus (79.0\% of captures), Mus spretus (12.8\%), Rattus norvegicus (4.7\%), and Eliomys quercinus $(3.5 \%)$. After controlling for the block effect $(z=1.56, P=0.059)$, we found higher rodent trappability beneath than away from $P$. bourgaeana trees $\left(F_{1,60}=4.40\right.$, $P=0.040$; Figure $2 \mathrm{~b}$ ), which is consistent with the above results. Also, "Cover" had a significant effect $\left(F_{1,60}=5.26\right.$, $P=0.0253)$, with, as expected, higher rodent trappability in Pistacia than in open microsites (Figure 2b). There was no significant interaction between "Tree" and "Cover" $\left(F_{1,60}=0.43, P=0.512\right)$, indicating that the higher trappability of rodents beneath trees compared to away from trees took place in both microsites (Figure 2b).

\section{Discussion}

\section{SEED DISPERSERS VERSUS SEED PREDATORS}

Frugivorous visitors clearly differed in the quality and quantity of seed dispersal, contributing to $P$. bourgaeana recruitment not only in different magnitudes, but also in opposite directions. Though rabbits and deer disperse a variety of fleshy-fruited species (see Study site), they damaged all $P$. bourgaeana seeds eaten and thus functioned as seed predators. Our expectation for rodents was corroborated because all evidence gathered during this study supported the conclusion that they were seed predators. However, since there is at least 1 species of rodent in the local community that is known to cache seeds (A. sylvaticus; Muñoz \& Bonal, 2007; Gómez et al., 2008), the possibility of secondary dispersal by seed-caching rodents (Vander Wall \& Longland, 2004; Forget et al., 2005) cannot be definitively ruled out. Also, small birds occasionally interacted with $P$. bourgaeana, behaving as pulp predators. In contrast to most tropical ecosystems, no large-sized frugivorous birds able to ingest whole $P$. bourgaeana fruit, or to transport them away from mother trees, occur in our Mediterranean study area. Certainly, the possibility that those species that are present eventually disperse a few $P$. bourgaeana seeds exists (e.g., seed dropping during fruit handling), but it is evident from this study that they essentially acted as seed or pulp predators (e.g., Mendoza \& Dirzo, 2007; Paine \& Beck, 2007). Because of these results, we include no additional discussion of the dispersal effectiveness of deer, rabbits, and rodents. Other aspects of carnivore and boar seed dispersal are considered below.

IMPORTANCE OF UNCOMMON AND ABUNDANT SEED DISPERSERS

As predicted, the rates of visitation of potential dispersers to fruiting trees were rather consistent with their recorded 
densities in Doñana (Table I), rabbits, deer, and boars being the most abundant species and more reliable visitors as compared with carnivores. This is consistent with null models and previous empirical evidence suggesting that the frequency of fruit-frugivore interactions is highly dependent on frugivore abundance (Burns, 2006). Nonetheless, a myriad of factors other than a disperser's abundance may affect the number of seeds dispersed by a particular species (e.g., feeding behaviour and food preferences, alternative foods, habitat selection; Russo, Portnoy \& Augspurger, 2006). Besides, the number of seeds found per survey in mammal feces clearly indicated that badgers transported more $P$. bourgaeana seeds (whether viable or not; see below) than both boars and foxes. Though it was not possible to estimate the number of fruits (or seeds) consumed per visit during the field experiments, it is possible that a higher feeding rate by badgers could ultimately compensate for their lower visitation rate to $P$. bourgaeana than boars (e.g., Russo, 2003). In the case of fox, both their lack of visitation to our experimental trees and our metric concerning the number of seeds transported indicated a lower number of dispersed seeds in relation to both badgers and boars. These results strongly indicate that badgers play an important role in $P$. bourgaeana dispersal despite their low density and low frequency of visit. Furthermore, data on seed treatment and germination strengthened the idea that badgers dispersed much more viable seeds than boars (Table II), and thus badger appears to be the main disperser of this tree.

Even so, the microsites of seed deposition by each disperser should be accounted for, as contrasting microsites may differ, for example, in post-dispersal seed survival (Herrera et al., 1994; Nathan \& Muller-Landau, 2000; Howe \& Miriti, 2004). Results from our seed predation experiment supported the idea that seed survival is positively distance-dependent; seeds carried away from mother trees, either to open microsites or to Pistacia shrubs, always showed higher survival than non-dispersed seeds (Figure 2a). This result points to a general advantage that dispersers (mostly badger but also boar and fox) provided to P. bourgaeana: they all routinely moved its seeds away from mother trees (Spiegel \& Nathan, 2007). Nevertheless, our results also showed that seed survival was not a mere function of distance to mother tree (LoGiudice \& Ostfeld, 2002; Kwit, Levey \& Greenberg, 2004). For instance, rodents were generally most active within Pistacia shrubs where badgers frequently deposited $P$. bourgaeana seeds; however, since there were no significant differences in survival between microsites for seeds dispersed away from mother trees, badger dispersal effectiveness did not change due to its selection of microsites for seed deposition. Our results nonetheless illustrate the need to account for microspatial variations in seed survival both beneath and away from mother plants in evaluating the benefits of seed dispersal (Augspurger, 1983; 1984; Hammond \& Brown, 1998). On the other hand, given that in our Mediterranean study area droughts kill a large fraction of $P$. bourgaeana seedlings (Fedriani \& Delibes, 2009), it is probable that conditions beneath Pistacia shrubs (e.g., soil temperature, moisture) are more favourable for seedling survival than those occurring in open microsites (Pugnaire \& Valladares, 2007), where fox and boar delivered many more seeds. Our field observations of $P$. bourgaeana emerging and getting established directly from badger latrines (i.e., feces deposited in small dugs and buried shallowly with loose substrate; J. M. Fedriani \& M. Delibes, unpubl. data) reinforce the idea that badgers are the most efficient dispersers (see also Fedriani \& Delibes, 2009).

\section{Conclusion}

Because data on number of seeds transported and quality of seed dispersal are laborious to gather (and lacking for most plant-disperser interactions), researchers use frequency of visits as a surrogate of plant reliance on visitors (Vázquez et al., 2005). This approach neglects important aspects of the dispersal service, which has been recently evidenced in a guild of tropical mammalian frugivores (Brodie et al., 2009). For instance, frugivorous visitors often act as pre-dispersal seed predators rather than as dispersers (Howe, 1980; Herrera, 1989; Fedriani \& Boulay, 2006; this study), fail to disperse handled seeds (Howe, 1980), or deliver them to unsuitable microsites (Willson \& Whelan, 1990; Schupp, 2007). Such poor dispersal service seems pervasive among both vertebrate- (e.g., Howe, 1977; 1980; Herrera, 1989; Gómez et al., 2008) and invertebratedispersed plants (see reviews in Beattie \& Hughes, 2002; Hulme \& Benkman, 2002), suggesting that the most frequent visitors are not necessarily the major seed dispersers (e.g., Russo, 2003; Brodie et al., 2009). By considering several contrasting aspects of the dispersal process (frequency of visits, number of handled seeds, post-dispersal seed survival, etc.) of a temperate mammal-dispersed species, we show that a less-inclusive approach would distort our interpretation of the tree level of generalization on dispersers. For instance, our data reveal visits of 7 frugivorous categories (2 carnivores, 2 ungulates, 1 lagomorph, rodents, and at least 1 bird species), suggesting a diverse assemblage of dispersers in $P$. bourgaeana, with the most frequent dispersers being disparate species such as red deer and rabbit, and infrequent dispersers including badger and some birds. However, when accounting for other aspects of dispersal, only 3 species acted as legitimate seed dispersers and just 1 species, the infrequent badger, seemed to carry out a large fraction of the overall dispersal service. Further, our seed germination trial strongly suggests that seeds ingested by badgers germinate more often that those ingested by boars and foxes. Of course, processes such as seedling survival and establishment can affect the overall dispersal service provided by mammals to $P$. bourgaeana (Herrera et al., 1994; Rey \& Alcántara, 2000; Balcomb \& Chapman, 2003); however, all evidence gathered during this study concerning both the quantity and the quality of dispersal makes clear that badger, a scarce species, plays a major role in $P$. bourgaeana dispersal.

Our study confirms the assumption based on fruit traits that mammals are the main dispersers of $P$. bourgaeana (Jordano, 1995). Rather than a "generalized mammalian syndrome" (sensu Herrera, 1989), we propose that the size of $P$. bourgaeana fruit and the fragile nature of its seeds match better the foraging behaviour and the masticatory 
system of omnivorous feeders (e.g., some carnivores, primates, even boars) as compared with some small- (e.g., rabbits) and large-sized herbivorous mammals (e.g., deer). Nonetheless, those plant traits likely evolved before the arrival of genus Pyrus in the Iberian Peninsula, in Central Asia, as proposed for the ancestor of numerous present-day plants (including the sweet apple, Malus pumila; Juniper \& Mabberly, 2006; Juniper, 2007). Furthermore, current ecological conditions are likely very different from the conditions under which the tree evolved in the western Mediterranean basin. For instance, during the last millennium at least 2 potential seed dispersers (wolf, Canis lupus [Valverde, 1967] and the brown bear, Ursus arctos [Swenson et al., 2000]) became extinct in Doñana, and further extinctions occurred during the Pleistocene (e.g., the Barbary macaque, Macaca sylvanis; Herrera, 1989). Finally, temporal and spatial inconsistencies in the abundance of extant frugivores (Herrera, 1998; 2002), as well as conflicting selection pressures by seed dispersers (carnivores, boar) and seed predators (rabbits, rodents, deer; e.g., Alcántara \& Rey, 2003; Martínez, García \& Obeso, 2007, Siepielski \& Benkman, 2007) make unlikely a tight adaptation between the tree and its dispersers. As the relative importance for plant reproduction of different animal counterparts is context dependent (Thompson, 2005), it is predictable that, under some circumstances (e.g., lack of abundant and efficient animal counterparts), uncommon species can play important roles in their mutualistic interactions with flowering plants, during both dispersal and pollination (Herrera, 2005; Aizen \& Harder, 2007).

\section{Acknowledgements}

We are indebted to G. Calvo, M. Váz, M. Zywiec, and innumerable volunteers for their enthusiastic field and lab assistance. We thank T. Paine, A. Green, S. Vander Wall, and two anonymous reviewers for comments on early drafts and J. Swenson for English review. The Spanish Ministerio de Medio Ambiente (15/2003 grant) and Ministerio de Educación y Ciencia (CGL2007-63488/BOS) supported this study.

\section{Literature cited}

Aizen, M. A. \& L. D. Harder, 2007. Expanding the limits of the pollen-limitation concept: Effects of pollen quantity and quality. Ecology, 88: 271-81.

Alcántara, J. M. \& P. J. Rey, 2003. Conflicting selection pressures on seed size: Evolutionary ecology of fruit size in a bird-dispersed tree, Olea europaea. Journal of Evolutionary Biology, 16: $1168-1176$.

Aldasoro, J. J., C. Aedo \& F. Muñoz-Garmendia, 1996. The genus Pyrus L. (Rosaceae) in south-west Europe and North Africa. Biological Journal of the Linnean Society, 121: 143-158.

Augspurger, C. K., 1983. Seed dispersal of the tropical tree Platypodium elegans, and the escape of its seedlings from fungal pathogens. Journal of Ecology, 71: 759-771.

Augspurger, C. K., 1984. Seedling survival of tropical tree species: Interactions of dispersal distance, light-gaps, and pathogens. Ecology, 65: 1705-1712.

Balcomb, S. R. \& C. A. Chapman, 2003. Bridging the gap: Influence of seed deposition on seedling recruitment in a primate-tree interaction. Ecological Monographs, 73: 625-642.
Beattie, A. J. \& L. Hughes, 2002. Ant-plant interactions. Pages 185-208 in C. M. Herrera \& O. Pellmyr (eds.). Plant-Animal Interactions: An Evolutionary Perspective. Blackwell Science, Oxford.

Bennington, C. C. \& W. V Thayne, 1994. Use and misuse of mixed model analysis of variance in ecological studies. Ecology, 75: 717-722.

Braza, F., F. Alvarez, R. Geldof \& H. Byloo, 1984. Desplazamientos de ungulados silvestres a través de una zona de ecotono en Doñana. Doñana, Acta Vertebrata, 11: 275-287.

Brodie, J. F., O. E. Helmy, W. Y. Brockelman \& J. L. Maron, 2009. Functional differences within a guild of tropical mammalian frugivores. Ecology, 90: 688-698.

Brown, J. S. \& B. P. Kotler, 2004. Hazardous duty pay and the foraging cost of predation. Ecology Letters, 7: 999-1014.

Burns, K. C., 2006. A simple null model predicts fruit-frugivore interactions in a temperate rainforest. Oikos, 115: 427-432.

Calviño-Cancela, M., 2002. Spatial patterns of seed dispersal and seedling recruitment in Corema album (Empetraceae): The importance of unspecialized dispersers for regeneration. Journal of Ecology, 90: 775-784.

Connell, J. H., 1971. On the role of natural enemies in preventing competitive exclusion in some marine animals and in rain forest trees. Pages 298-312 in P. J. den Boer \& G. R. Gradwell (eds.). Dynamics of Populations. Center for Agricultural Publication and Documentation, Wageningen.

Dellafiore, C. M., J. B. Gallgo-Fernádez \& S. Munoz-Vallés, 2007. The contribution of endozoochory to the colonization and vegetation composition of recently formed sand coastal dunes. Research Letters in Ecology, DOI: 10.1155/2007/74090.

Eycott, A. E., A. R. Watkinson, M.-R. Hemami \& P. M. Dolman, 2007. The dispersal of vascular plants in a forest mosaic by a guild of mammalian herbivores. Oecologia, 154: 107-118.

Fedriani, J. M., 1996. Dieta anual del zorro, Vulpes vulpes, en dos hábitats del Parque Nacional de Doñana. Doñana, Acta Vertebrata, 23: 143-152.

Fedriani, J. M., 2005. Do frugivorous mice choose where or what to feed on? Journal of Mammalogy, 86: 576-586.

Fedriani, J. M. \& R. Boulay, 2006. Foraging by fearful frugivores: Combined effect of fruit ripening and predation risk. Functional Ecology, 20: 1070-1079.

Fedriani, J. M. \& M. Delibes, 2009. Functional diversity in fruitfrugivore interactions: A field experiment with Mediterranean mammals. Ecography, DOI: 10.1111/j.0906-7590.2009.05925.x

Fedriani, J. M., P. Ferreras \& M. Delibes, 1998. Dietary response of the Eurasian badger, Meles meles, to a decline of its main prey in the Doñana National Park. Journal of Zoology, 245: 214-218.

Fedriani, J. M. \& M. Kohn, 2001. Genotyping feces links individuals to their diets. Ecology Letters, 4: 477-483.

Fedriani, J. M. \& A. J. Manzaneda, 2005. Pre- and post-dispersal seed predation by rodents: Balance of food and safety. Behavioral Ecology, 16: 1018-1024.

Fedriani, J. M., F. Palomares \& M. Delibes, 1999. Niche relations among three sympatric Mediterranean carnivores. Oecologia, 121: 138-148.

Fedriani, J. M., P. Rey, J. L. Garrido, J. Guitian, C. M. Herrera, M. Mendrano, A. Sanchez-Lafuente \& X. Cerda, 2004. Geographical variation in the potential of mice to constrain an ant-seed dispersal mutualism. Oikos, 105: 181-191.

Fedriani, J. M., T. Wiegand \& M. Delibes, 2009. Spatial pattern of adult trees and the mammal-generated seed rain in the Iberian pear. Ecography. DOI 10.1111/j.1600-0587.2009.06052.x. 
Fernández-Llario, P., 1996. Ecología del jabalí en Doñana: biología reproductiva e impacto ambiental. Ph.D. thesis. Universidad de Extremadura, Cáceres.

Forget, P.-M., J. E. Lambert, P. E. Hulme \& S. B. Vander Wall, 2005. Seed Fate: Predation, Dispersal and Seedling Establishment. CABI Publishing, Cambridge, Massachusetts.

Giladi, I., 2006. Choosing benefits or partners: A review of the evidence for the evolution of myrmecochory. Oikos, 112: 481-492.

Gómez, J. M., C. Puerta-Piñero \& E. W. Schupp, 2008. Effectiveness of rodents as local seed dispersers of Holm oaks. Oecologia, 155: 529-537.

Hammond, D. S. \& V. K. Brown, 1998. Disturbance, phenology and life-history characteristics: Factors influencing distance/densitydependent attack on tropical seeds and seedlings. Pages 51-78 in D. M. Newbery, H. H. T. Prins \& N. Brown (eds.). Dynamics of Tropical Communities: $37^{\text {th }}$ Symposium of the British Ecological Society. Cambridge University Press, Cambridge.

Herrera, C. M., 1987. Vertebrate-dispersed plants of the Iberian Peninsula: A study of fruit characteristics. Ecological Monographs, 57: 305-331.

Herrera, C. M., 1989. Frugivory and seed dispersal by carnivorous mammals, and associated fruits characteristics, in undisturbed Mediterranean habitats. Oikos, 55: 250-262.

Herrera, C. M., 1998. Long-term dynamics of Mediterranean frugivorous birds and fleshy fruits: A 12-yr study. Ecological Monographs, 68: 511-538.

Herrera, C. M., 2002. Seed dispersal by vertebrates. Pages 185-208 in C. M. Herrera \& O. Pellmyr (eds.). Plant-Animal Interactions: An Evolutionary Perspective. Blackwell Science, Oxford.

Herrera, C. M., 2005. Plant generalization on pollinators: Species property or local phenomenon? American Journal of Botany, 92: 13-20.

Herrera, C. M., P. Jordano, L. López Soria \& J. A. Amat, 1994. Recruitment of a mast-fruiting, bird-dispersed tree: Bridging frugivore activity and seedling establishment. Ecological Monographs, 64: 315-344.

HilleRisLambers, J., J. S. Clark \& B. Beckage, 2002. Density dependent mortality and the latitudinal gradient in species diversity. Nature, 417: 732-735.

Howe, H. F., 1977. Bird activity and seed dispersal of a tropical wet forest tree. Ecology, 58: 539-550.

Howe, H. F., 1980. Monkey dispersal and waste of neotropical fruit. Ecology, 105: 944-959.

Howe, H. F. \& M. N. Miriti, 2004. When seed dispersal matters. BioScience, 54: 651-660.

Howe, H. F. \& J. Smallwood, 1982. Ecology of seed dispersal. Annual Review of Ecology and Systematics, 13: 201-228.

Hulme, P. E. \& C. W. Benkman, 2002. Granivory. Pages 132154 in C. M. Herrera \& O. Pellmyr (eds.). Plant-Animal Interactions. Blackwell Science, Oxford.

Hyatt, L. A., M. A. Rosenberg, T. G. Howard, G. Bole, W. Fang, J. Anastasia, K. Brown, R. Grella, K. Hinman, J. P. Kurdziel \& J. Gurevitch, 2003. The distance dependence prediction of the Janzen-Connell hypothesis: A meta-analysis. Oikos, 103: 590-602.

Janzen, D. H., 1970. Herbivores and the number of tree species in tropical forests. American Naturalist, 104: 501-528.

Jordano, P., 1984. Relaciones entre plantas y aves frugívoras en el matorral mediterráneo del área de Doñana. Ph.D. thesis. Universidad de Sevilla, Sevilla.

Jordano, P., 1995. Angiosperm fleshy fruits and seed dispersers: A comparative analysis of adaptation and constraints in plant-animal interactions. American Naturalist, 145: 163-191.
Jordano, P. \& E. W. Schupp, 2000. Seed dispersal effectiveness: The quantity component and patterns of seed rain for Prunus mahaleb. Ecological Monographs, 70: 591-615.

Juniper, B. E., 2007. The mysterious origin of the sweet apple. American Scientist, 95: 44-51.

Juniper, B. E. \& D. J. Mabberly, 2006. The Story of the Apple. Timber Press, Portland, Oregon.

Kufner, M. B., 1986. Tamaño, actividad, densidad relativa y preferencia de hábitat de los pequeños y medianos mamíferos de Doñana, como factores condicionantes de su tasa de predación. Ph.D. thesis. Universidad Autónoma de Madrid, Madrid.

Kwit, C., D. J. Levey \& C. H. Greenberg, 2004. Contagious seed dispersal beneath heterospecific fruiting trees and its consequences. Oikos, 107: 303-308.

Littell, R. C., G. A. Milliken, W. W. Stroup \& R. D. Wolfinger, 1996. SAS System for Mixed Models. SAS Institute Inc., Cary, North Carolina.

LoGiudice, K. \& R. S. Ostfeld, 2002. Interactions between mammals and trees: Predation on mammal-dispersed seeds and the effect of ambient food. Oecologia, 130: 420-425.

Martínez, I., D. García \& J. R. Obeso, 2007. Allometric allocation in fruit and seed packaging conditions the conflict among selective pressures on seed size. Evolutionary Ecology, 21: 517-533.

Mendoza, E. \& R. Dirzo, 2007. Seed-size variation determines interspecific differential predation by mammals in a neotropical rain forest. Oikos, 116: 1841-1852.

Muñoz, A. \& R. Bonal, 2007. Rodents change acorn dispersal behaviour in response to ungulate presence. Oikos, 116: 1631-1638.

Nathan, R. \& H. C. Muller-Landau, 2000. Spatial patterns of seed dispersal, their determinants and consequences for recruitment. Trends in Ecology and Evolution, 15: 278-284.

Paine, C. E. T. \& H. Beck, 2007. Seed predation by neotropical rainforest mammals increases diversity in seedling recruitment. Ecology, 88: 3073-3087.

Palomares, F., P. Ferreras, J. M. Fedriani \& M. Delibes, 1995. Spatial relationships between Iberian lynx and other carnivores in an area of south-western Spain. Journal of Applied Ecology, 33: 5-13.

Palomares, F., M. Delibes, E. Revilla, J. Calzada \& J. M. Fedriani, 2001. Spatial ecology of the Iberian lynx and abundance of its primary prey, the European rabbit, in southwestern Spain. Wildlife Monographs, 148: 1-36.

Peters, H. A., 2003. Neighbour-regulated mortality: The influence of positive and negative density dependence on tree populations in species-rich tropical forests. Ecology Letters, 6: 757-765.

Pugnaire, F. I. \& F. Valladares, 2007. Functional Plant Ecology. CRC publishers, Boca Raton, Florida.

Rey, P. J. \& J. M. Alcántara, 2000. Recruitment dynamics of a fleshy-fruited plant (Olea europaea): Connecting patterns of seed dispersal to seedling establishment. Journal of Ecology, 88: 622-633.

Rey, P. J., J. L. Garrido, J. M. Alcántara, J. M. Ramírez, A. Aguilera, L. García, A. J. Manzaneda \& R. Fernández, 2002. Spatial variation in ant and rodent post-dispersal predation of vertebrate-dispersed seeds. Functional Ecology, 16: 773-781.

Russo, S. E., 2003. Responses of dispersal agents to tree and fruit traits in Virola calophylla (Myristicaceae): Implications for selection. Oecologia, 136: 80-87.

Russo, S. E., S. Portnoy \& C. K. Augspurger, 2006. Incorporating animal behavior into seed dispersal models: Implications for seed shadows. Ecology, 87: 3160-3174. 
SAS Institute, 2003. SAS OnlineDoc ${ }^{\circledR}$ 9.1. SAS Institute Inc., Cary, North Carolina.

Santos, T., J. L. Tellería \& E. Virgós, 1999. Dispersal of spanish juniper Juniper thurifera by birds and mammals in a fragmented landscape. Ecography, 22: 193-204.

Schupp, E. W., 1993. Quantity, quality and the effectiveness of seed dispersal by animals. Vegetation, 107/108: 15-29.

Schupp, E. W., 2007. The suitability of a site for seed dispersal is context-dependent. Pages 445-462 in A. J. Dennis, R. J. Green, E. W. Schupp \& D. A. Westcott (eds.). Seed Dispersal: Theory and Its Application in a Changing World. CAB International, Wallingford.

Siepielski, A. M. \& C. W. Benkman, 2007. Convergent patterns in the selection mosaic for two North American bird-dispersed pines. Ecological Monographs, 77: 203-220.

Soriguer, R. C., 1983. Consideraciones sobre el efecto de los conejos y los grandes herbívoros en los pastizales de la Vera de Doñana. Doñana, Acta Vertebrata, 10: 155-168.

Spiegel, O. \& R. Nathan, 2007. Incorporating dispersal distance into the disperser effectiveness framework: Frugivorous birds provide complementary dispersal to plants in patchy environments. Ecology Letters, 10: 718-728.
Swenson, J. E., N. Gerstl, B. Dahle \& A. Zedrosser, 2000. Action plan for the conservation of the brown bear in Europe (Ursus arctos). Nature and Environment, 114: 1-70.

Thompson, J. N., 2005. The Geographic Mosaic of Coevolution. University of Chicago Press, Chicago, Illinois.

Váldés, B., V. Girón, E. Sánchez-Gullón \& I. Carmona, 2007. Catálogo florístico del espacio natural de Doñana (so de España). Plantas vasculares. Lagascalia, 27: 73-362.

Valverde, J. A., 1967. Estructura de una comunidad de vertebrados terrestres. Monografías de la Estación Biológica de Doñana, 1: $1-218$.

Vander Wall, S. B. \& W. S. Longland, 2004. Diplochory: Are two seed dispersers better than one? Trends in Ecology \& Evolution, 19: 155-161.

Vázquez, D. P., W. F. Morris \& P. Jordano, 2005. Interaction frequency as a surrogate for the total effect of animal mutualists on plants. Ecology Letters, 8: 1088-1094.

Wang, B. C. \& T. B. Smith, 2002. Closing the seed dispersal loop. Trends in Ecology and Evolution, 17: 379-385.

Willson, M. F. \& C. J. Whelan, 1990. Variation in postdispersal survival of vertebrate-dispersed seeds: Effects of density, habitat, location, season, and species. Oikos, 57: 191-198. 